\title{
On the Metalanguage of Modern Arabic Lexicography
}

\author{
Olzhas Mirzakhanovich Shayakhmetov ${ }^{1}$ \\ ${ }^{1}$ University of Nur-Mubarak, Almaty, Kazakhstan \\ Correspondence: Olzhas Mirzakhanovich Shayakhmetov, Al-Farabi ave, 73, Almaty, 050060, Kazakhstan.
}

$\begin{array}{lcc}\text { Received: February 28, } 2015 & \text { Accepted: March 20, } 2015 \quad \text { Online Published: April 24, } 2015 \\ \text { doi:10.5539/res.v7n6p209 } & \text { URL: http://dx.doi.org/10.5539/res.v7n6p209 }\end{array}$

\begin{abstract}
Describes the situation in meta-linguistic structure of a modern Arabic lexicography and raises the problem of doublets and triplets which are present in lexicographical Arabic terminology. Here, we analyze many terms used in scientific Arabic literature which accepted as equivalents to common terms in the "world" of lexicography. This study tells us that despite having a rich Arabic culture, particularly in practical Arabic lexicography, there is a problem in a unified formulation of modern Arabic lexicographical terms, which in turn points at the incompleteness of the linguistic analysis.
\end{abstract}

Keywords: meta-language, lexicography, lexicology, dictionary

\section{Introduction}

Modern Arabic lexicography has not just one but many pressing issues, especially when it comes to its description. One of the drawbacks of modern Arabic dictionaries is seen when describing a dictionary in its original form or the way we see it or the way we would like to see it based on the experience of a modern linguistic science such as terms, content, compilation methods, and pedagogical, social and cultural functions of the dictionary. In order to conduct a research in any field of science one should know the language of the field in which he/she will do research in and this is called meta-language (Malbakov, 2003). Therefore, it is important to know existing concepts and structural terms which predominate in a modern Arabic scientific literature.

The meta-language is seen as a "second-order" language in relation to natural human language which is perceived as a subject of a linguistic research. This term initially was originated in math and logic. It was defined as formal language by which properties of a subject and object theories can be researched and described and which is perceived as a system of inventory terms (Linguistic encyclopedic dictionary, 1990). Thus, meta-linguistic system including its concepts and terminology of a specific field of science are important means of describing the existing pattern. Meta-language acts as a reflection of a scientific, conceptual or theoretical principle of scientific discipline and that is why, essential part of it is associated with terminology.

The meta-language of linguistics, on the one hand, is based on a systemic ratio of terms and on the other hand it is based on general scientific vocabulary, i.e. words and phrases needed to describe various aspects of the linguistic research. According to Gvishiani, who performed a research in this field, development of the meta-linguistic system is the final stage of linguistic analysis. Gvishiani believes that linguistics can be divided into three aspects: a) the study of language sources b) the formation of concepts, and c) the formation of the meta-language (Gvishiani, 1983). Our lexicographers describe the process as follows: 'First, the language sources are introduced to a scientific community. After that, formation of concepts begins based on a primary concept. And then, the formed concepts receive names. One of the few variants which are more close to the term by definition can be used more frequently than others or may prove its superiority from the scientific point of view, so then it can take its place as a term in science' (Malbakov, 2003, p. 47). Therefore, it's obvious that term variation of the formed concepts used in science indicates incompletion of linguistic analysis staging.

In the second half of the last century many published studies initiated the formation of scientific thesaurus of a modern Arabic lexicography. Scientists such as Husain Nassar, Mahmoud Fahmi Hegazi, Ali al-Qasimi, Ahmad Mukhtar Omar, Mohammed Rashad al-Hamazawi, Abd al-'Āli al-Wadghīrī were the first who raised theoretical and practical problems of the modern Arabic dictionary as well as raised an issue on standardization of lexicographic terms.

Meta-language in modern linguistics is used to describe a particular concept as well as to study terminology of separate branches of linguistics. In lexicography meta-language means language of description of lexical units, 
i.e. meta-language of a dictionary. In its broadest sense, meta-language in lexicography means a language which covers general lexicographic terms, i.e. meta-language of lexicography. General lexicographic meta-language structure consists of terms such as lexicography and dictionary (general dictionary / monolingual dictionary / explanatory dictionary, belingual dictionary, multilingual dictionary, etc.).

\section{Methods}

This article raises the problem of excessive variation of the terms, doublets and triplets used in relation to the same concept in one field of science. This article assesses several general lexicographic meta-linguistic terms. It is not aimed at providing definition to well-known concept. It is aimed at analyzing the application of lexicographic terms and their definitions in a modern work of Arabic literature.

In the historical analysis of those few selected terms of Arabic lexicography, historical and analytical methods were used. While defining some similar and different features of vocabularies, particularly in Arabic and English lexicography, the leading methods were contrastive typological and comparative analysis. While the method of modeling was used in the study of word-formation terms resources, the component analysis was used in describing their semantic structure.

\section{Results}

The question of the modalities, selection criteria and methods of lexicographic description of subject area "lexicography", taking into account the specificities and experiences of Arab terminology, is by far the most outstanding in the field of Arabic linguistics. It is worth noting that the Arab branch of lexicography, so experienced in compiling dictionaries, gave the world the most valuable literary artifacts, registrating the lexicographic development of Arab literary language for fourteen centuries. It also gave the world a huge range of modern terminological dictionaries but at present it cannot offer a dictionary devoted to the description of lexicographical terminology only, while its existence is certainly necessary in the process of resolving difficulties of usage, unification and systematic descriptions of specific terminology in this field of knowledge.

\subsection{Lexicography}

Modern works on Arabic lexicography do not miss the opportunity to give a contrastive description to terms such as "Lexicography" and "Lexicology" with the obligatory indication of the differences between them. Typically, definitions come from European sources together with translated Arabic quotations. So the problem lays not so much on the existence of broad variations of definitions in foreign sources, but rather in the lack of a unified formulation of those terms in Arabic.

In 1962, the Academy of the Arabic Language in Cairo approved term "al-mu'jamāt" as an equivalent for the terms such as "Lexigraphie-Lexicography" and "Lexicologie-Lexicology" with following definition: "The collection and classification of language lexis regarding its semantic, structural and fundamental qualities' (A set of scientific and technical terminology, 1962, p. 94). This definition which covers both concepts could not leave Arabic lexicographers indifferent. Professor Muhammad Rashad al-Hamazawi noted that despite close relationship, two concepts represent completely different types of sciences, each of which has its own definitions and objectives. Muhammad Rashad al-Hamazawi considered the term "al-mu'jamiyāt" approved by the Academy the most suitable equivalent for the term "Lexicography". In contrast, due to vastness of this field of science the term "Lexicology" was suggested as an option in the form of artificial Masdar "al-mu'jamiya" with the meaning of abstract concept of theoretical science (Al-Hamazawi, 1984).

Table 1. Terms used to indicate "lexicography" and "lexicology" by several Arabic authors

\begin{tabular}{llll}
\hline Author & Reference & "Lexicography” & "Lexicology" \\
\hline $\begin{array}{l}\text { Prof. Mahmoud Fahmi } \\
\text { Hegazi }\end{array}$ & $\begin{array}{l}\text { Linguistic research "sinā'a al-mu'jamāt" } \\
\text { (Hegazi, 1994) }\end{array}$ & "ilm al-mu'jamāt" \\
$\begin{array}{l}\text { Prof. Ahmad Mukhtar } \\
\text { Omar }\end{array}$ & $\begin{array}{l}\text { Modern lexicography "al-mu'jamiya” } \\
\text { (Omar, 2009) }\end{array}$ & "al-mufradatia" \\
Prof. Ali al-Qasimi & $\begin{array}{l}\text { Arabic lexicography: "sina'a al-mu'jam" } \\
\text { theory and practice } \\
\text { (Al-Qasimi, 2003) }\end{array}$ & "“ilm al-mu'jam" \\
\hline
\end{tabular}




\begin{tabular}{|c|c|c|c|}
\hline Prof. Hulmi Halil & $\begin{array}{l}\text { Practical and theoretical } \\
\text { problems of linguistics } \\
\text { in the work of Ibn Farisa } \\
\text { (Halil, 2009) }\end{array}$ & $\begin{array}{l}\text { “iilm al-ma’ājim”, } \\
\text { “ilm al-ma’ājim at-tatbiqy”, } \\
\text { "fann sinā'a al-mā’ajim" }\end{array}$ & $\begin{array}{l}\text { "“ilm } \\
\text { al-ma’ājiman-nazary" }\end{array}$ \\
\hline Groups of authors & $\begin{array}{l}\text { General glossary of } \\
\text { linguistic terms (Unified } \\
\text { terminology of } \\
\text { linguistics, 1989) }\end{array}$ & $\begin{array}{l}\text { “sinā’a al-ma'ājim”, } \\
\text { "mu'jamiyāt" }\end{array}$ & $\begin{array}{l}\text { "dirasa al-mufradāt", } \\
\text { “"ilm matn al-luga", }\end{array}$ \\
\hline $\begin{array}{l}\text { Prof. Abd as-Salam } \\
\text { al-Misaddi }\end{array}$ & $\begin{array}{l}\text { Linguistics dictionary } \\
\text { (Misaddi, 2009) }\end{array}$ & "qāmūsiya" & "mu'gamia" \\
\hline Groups of authors & $\begin{array}{l}\text { Dictionary of terms of a } \\
\text { modern linguistics } \\
\text { (Glossary of modern } \\
\text { linguistics, 1983) }\end{array}$ & “sinā’a al-mu’jam” & "dirasa al-mufradāt" \\
\hline Prof. Ahmad al-'Āyed & $\begin{array}{l}\text { Concerning the issue on } \\
\text { a modern Arabic } \\
\text { lexicography ('Âyed, } \\
\text { 1987) }\end{array}$ & "ma’ājimiya" & "mu’jamiya" \\
\hline $\begin{array}{l}\text { Prof. Abd al-Āli } \\
\text { al-Wadghiri }\end{array}$ & $\begin{array}{l}\text { Problems of Arabic } \\
\text { dictionary (Al-Wadghiri, } \\
\text { 1989) }\end{array}$ & “'ilm as-sinā’a al-qāmūsiya” & “"ilm dirāsa al-alfāz" \\
\hline
\end{tabular}

Term “'ilm al-mu'gam” has following synonyms:

“sinā’a al-mu’jamāt”, "al-mu’jamiya”, “ma'ajimia”, "ilm al-ma’ajim”, “ilm al-ma'ajim at-tatbiqy”, "fann sina’a al-ma'ajim”, “'ilm as-sinā’a al-qāmūsiya”.

Considering definitions of the term "Lexicography" cited in linguistic encyclopedias we believe that each equivalent suggested by Arabic authors corresponds to the following definitions:

- Theoretical aspect or set of theoretical foundations needed for the development of dictionary

- Practical aspect or the same process of developing a dictionary (Hartmann, 1983)

- Practical art of developing a dictionary (which is not science) is not considered an independent branch of linguistics, but forms a part of semantics (Asher, 1994).

- Theories and methods of developing a dictionary (Svenson, 1993).

For many years, lexicography was seen primarily as a practice of compiling dictionaries, generally not by chance, because the practice goes largely ahead of theory. According to R.R.K. Hartmann, lexicography can be divided into applied and theoretical disciplines, where the first is the history of dictionaries and their lexicographic analysis, typology, the use and structure, and the second is the collection of the material, editing and publication of dictionaries (Hartmann, 1983). Therefore, the existence of such equivalents of this term in Arabic as "al-sina'a mu'jamaat" (compiling dictionaries), "fann sina'a al-ma'ajim" (the art of compiling dictionaries) is rightly grounded.

If so, then suggested equivalents are more suitable to describe these concepts rather than their equivalents. Moreover, table 1 shows that it is quite difficult to understand by which criteria distinction was made between the terms "Lexicography" and "Lexicology" as for first version proposed singular form is "al-mu'jamiya", and for the second version the plural form is "al-ma'ajimia" or for both concepts apply equivalents which are considered synonymous in everyday life and are used to indicate the same meaning, i.e. "qāmūsiya", "mu'jamiya".

Given the original meaning of the terms "Lexicology" (Ancient Greek: Logos: "judgment", "the concept") and "Lexicography" (Ancient Greek: Grafo: "to write") it would be logical to assume that more closer equivalents received by tracing would be the terms proposed by Prof. M. F. Hijazy and Prof. Ali al-Qasimi such as "iilm al-mu'jamāt" or "'ilm al-mu'jam" (science dealing with the study of lexis) and "sinā'a al-mu'jamāt" "iim al-mu'jam", (registration of examined lexis) . 
On this occasion, Professor Ali al-Qasimi in his book "Theory and practice of Arabic lexicography" defined aforementioned concept as:

“'ilm al-mu'jam" is a term referring to the science of lexis dealing with the study of spoken words, their morphological, structural, semantic properties, synonyms, homonyms, phraseologisms, idioms and expressions and all lexical materials which form a dictionary. The term "sinā'a al-mu'jam" indicates the process of compiling the dictionary which is consisted of five major stages: data collection, selection of the glossary, distribution of entries in a particular order, writing the material and the publication of the completed result (Al-Qasimi, 2003). According to al-Qasimi, the term "al-mu'jamiya", encompasses the meaning of both concepts (Al-Qasimi, 2003).

\subsection{Dictionary}

The next term which is present in scientific thesaurus in modern Arabic lexicography is "mu'jam" (Dictionary) or "a book in which lexis is collected and put in alphabetical order" (Intermediate dictionary of Arabic dictionary, 2011, p. 207). Nowadays most of the Arabic dictionaries are called "mu'jam" (Dictionary) regardless of their form and function. Despite the fact that the first Arab dictionaries appeared in VIII century, the term "mu'jam" with the meaning of Dictionary came into use only in the second half of the twentieth century.

As a consequence of the growing interest of Muslims to the Holy Quran, to sayings of the Prophet and desire to clarify the hidden meaning in them (garib), primary works which represented some kind of a "glossary" intended to clarify hidden lexis of the Quran and Hadith and were called "garīb al-qur'ān" or "garīb al-hadith". Other works which thematically described the lexis associated with the human body, body parts of camels and other animals, names of plants, military lexis were called "kitāb", i.e. "The Book of horses", "The Book of camels", "The Book of birds", etc., the authors of which were outstanding linguists of their time such as al-Kisa (died in 816), Al-Shamil Nadra bin (died in 820), Kutrub (died in 822), etc. Up until the middle of the XIX century authors of dictionaries tended to name their work with metaphorical titles such as "al-muhit" (ocean), "al-muhkam" (bright), "al-qāmūs" (the ocean bed). One of the examples is dictionary Butrus al-Bustani (1819-1883) called "muhīt al-muhït" which means "the ocean in the ocean". The first general dictionaries such as "kitābal-'ain" Khalil bin Ahmad (719-792) or "al-jīm" Abu Omar al-Shaybani (died in 822) were named with Arabic letters (Al-Qasimi, 2003).

Some works from the earlier period had a description "mu'jam", however, they had a reference meaning and were not used for description and clarification of ambiguous lexis, but served as a directory to the names of companions of the Prophet and deliverers of Hadith, and were put in the alphabetical order. There is a perception which states that the first who applied the word "mu'jam" in the name of work was al-Buhari (809-869), then Ahmad bin Ali bin Al-Musni (pp. 826-920) in the book "mu'jam" and Abu Al-Kasin Al-Bagawi in the book "mu'jam as-sahāba" used the word "mu'jam" in naming of their works.

With the similar title works were published on other areas, namely "mu'jam al-'udabā" (the directory of names and biographies of learned men) and "mu'jam al-buldān" (geographical directory) of Yākūt Al-Hamaui, "mu'jam aš-šu' arā" (directory of names and biographies of poets) of Abu 'Ubaidulla Al-Marzubani and others (Omar, 1988). Nevertheless, none of the above authors of the mentioned works implied under the word "mu'jam" meaning of the word "dictionary", but proceeded from its linguistic meaning. The word "mu'jam" is derived from the verb "a'jama" which has a three-letter root "“ain-gim-mim". Ibn Djinni, the famous linguist scientist of the X century, providing description of the meaning of this word said "Know, that (root) "'ain-gim-mim" in the speech of arabs has a meaning of "ambiguity" and "stealthiness", which contradict "clarity" and "apprehensibility", hence their words: "rajul a'jam" or "imra'a'ajmā", when defining man or woman who are not able to produce clear and comprehensive speech'. The form "af'ala" may mean "negation" of the meaning of primary root.., therefore, when we say "a'jamtu al-kitāb" we imply "I eliminated obscurity in the book", "I explained the book" (Ibn Djinni, 1993, p. 36, p. 39). Hence, the meaning of the passive voice "mu'jam", i.e. "clarified".

At the present day, there are many modern Arabic dictionaries which have a title "mu'jam". The most popular are the dictionaries of Academy of the Arabic Language in Cairo, initially released in 1960 year; repeatedly republished dictionary "al-mu'jam al-uasît" (Intermediate dictionary), its lightweight version "al-mu'jam al-uajīz" (Intermediate dictionary) and being at the final stage of production its multivolume edition "al-mu'jam al-kabiir" (large dictionary), as well as "Laros" association dictionary titled as "al-mu'jam al-'araby al-hadīth" (modern Arabic dictionary), published in the year 1987; dictionary "mu'jam al-'araby al-asāsı̄” (basic Arabic dictionary), published in 1989 by Arab League Educational, Cultural and Scientific Organization, ALECSO (Mukhtar, 1988; Al-Qasimi, 2003). 
Another widely known term meaning "dictionary" is "qāmūs". As mentioned earlier, amongst medieval lexicographers there was a tradition to name their works metaphorically, giving them the attributes of the deep ocean or the bottomless sea, representing the source of infinitely rich vocabulary of the Arabic language, for example, "al-'ubāb" (the abyss of the sea), "al-muhīt" (the ocean). One of such work pieces belongs to Madj Al-Din Muhammad bin Ya'qūb Al-Fīrūzabādī, who gave his dictionary a title "al-qāmūs al-muhīt", i.e. "ocean bed". All the advantages and disadvantages of antecedent dictionaries were considered in this new dictionary, which has a lesser volume and was easier to use, and its lexical material served as the basis for many subsequent works. Consequently, the dictionary received a great popularity and the word "qāmūs" which was used as a name of the dictionary and was later applied in other lexis collections.

As noted by Professor A. al-Qasimi, in accordance with Dr. Abbas as-Suri, one of the first who raised the issue with problematic terms "mu'jam" and "qāmūs", the latter of these terms is not the only one affected by this transformation of meaning. As stated by A. Al-Qasimi the scenario could be repeated with the dictionary of Luis Maluf "al-munjid fi lugha al-adab wa al-'ulūm" (the assistant in language, literature and sciences), which received a great popularity amongst international students who started to use the word "al-munjid" as a synonym for the word "mu'jam" (Al-Qasimi, 2003). It remains to add that the professor's fears were justified. It is not by chance that the name of this work is entirely mentioned in the dictionary of Baranov, where it is not described as "the language assistant" but has a direct translation "al-Mundjid" with an explanation: "Arabic language dictionary" (Baranov, 2002). As a matter of fact L. Maluf was not the only one author who named his dictionary "al-munjid". Similarly, other dictionaries have the same titles "al-munjid al-'araby al-faransyliat-tuläb" (Arabic-French student dictionary) of Joseph Baum Hadjar, "munjid al-lugha al-'arabya al-mu'āsira" (modern Arabic dictionary) of Subhi Hamawi, where the word "munjid" clearly indicates the meaning of "dictionary".

\subsection{Lexicon and Dictionary}

Thus, it became known to us that the term "mu'jam" with the meaning "dictionary" has synonyms, one of which is "qāmūs". Virtually, one of the main functions of the synonymy in the literary language is the function of replacement, when semantically appropriate units interchange and relieve the monotonous repetition of the same words (Linguistic Encyclopedic Dictionary, 1990). It is extremely undesirable phenomenon when in the system terminology each term directly and explicitly indicates denoted synonymy. Raising the question on the presence of doublets and triplets in the terminology of the Arabic lexicography, the professor Ali Al-Kasimi stated 'Modern terminology seeks to allocate one term for the same concept in the semantic field of a single scientific area, resulting in a term designated to only one concept, and one concept would refer to only one term. For this reason it is necessary to eliminate homonyms and synonyms from the terms' (Al-Qasimi, 2003, p. 7). In other words, the scientist insists that each term claimed only one scientific definition and had clear key descriptors that would accurately and plainly disclose the nature of the specific event, selecting the most suitable terms at the same time.

However, instead of "eliminating", the Arabic linguists prefer to clarify definitions of the identical by meaning terms via narrowing the scope of use for each term. Therefore, until recently similar terms "mutarjim" and "tarjumān" referred to an individual involved in the translation from one language to another. Presently, due to scientific and technological progress, development of international relations and expanding of the field of translation activity, the term "mutarjim" is widely applied in relation to the specialist engaged in written translation, whereas the term "tarjumān" is used to designate the person performing simultaneous interpretation (Al-Qasimi, 2003). To clarify the meaning denoted by synonyms, there is usually a focus on the divergent sememes, which in turn open new sides in the denoting objects. In our case, divergent sememes in each of the terms "mu'jam", "qāmūs" are acceptable to use to clarify their definitions.

In the investigations of the field of linguistics at the end of $20^{\text {th }}$ century scientists started to differentiate between definitions such as "Lexicon", indicating the vocabulary available in some language group including all of the group members, and "Dictionary", pointing at a collection of words, selected and ranked in a certain order in the lexicographical manual indicating to them the language and encyclopedic explanations. Therefore, modern Arab linguists, for example, Abd al-Āli al-Wadghiri prefer to use the doublet terms "mu'jam" and "qāmūs", where the first term would be applied to define the concept "Lexicon", and the other term pointing to the meaning "Dictionary" (Udghiri, 1998).

\subsection{Belingual, Multilingual and Explanatory Dictionary}

Another scientist, who insisted on clarification of definitions of terms "mu'jam", "qāmūs" was Pr. Laila Masudi. After analyzing a number of Arabic dictionaries on the criteria of their specificity and purpose, the scientist came to a conclusion that the most appropriate term for "qāmūs" is "explanatory dictionary", while the term "mu'jam" 
provides a meaning of bilingual and multilingual dictionary with no encyclopaedic reference, where the vocabulary entry is limited by provision of equivalents of vocabulary units without their descriptions (Al-Mas'udi, 1998).

The consequences could look simpler if scientific descriptions of these terms derived from the presently available sources of world linguistics, the same way it happened with terms "Lexicology" and "Lexicography" which were mentioned earlier. In fact, the terms "mu'jam" and "qāmūs" appeared before the era of the dawn of the world of linguistics at the end of XIX century and middle of the last century, and each of the terms is individually motivated for designation of the meaning "dictionary" and is based on the origins, stretching deep into the Arabic linguistic heritage and having their own unlike other conceptual norms. Consequently, terms, related to one conceptual system, in our case deriving from the Arabic linguistic tradition, cannot be subordinated to the other conceptual system, which in turn is derived from the Western linguistic tradition.

\section{Discussion}

Arabic linguistic tradition has been developing independently over fifteen centuries and consequently, it has own ways of finding a solution to the pressing issues of today's Arabic linguistics. Practical Arabic lexicography is distinguished by its characteristics, methods for speech interpretation and grammatical content of the dictionary. Long before the appearance of the first European dictionaries, Arab lexicographers for the interpretation of the lexis used methods such as written fixation of sound characteristics of speech segments (transcription) to obscure the difficult lexis as well as used illustrations, quotations and encyclopedic information. Today, there are many formal institutions at the international level which are aimed at addressing these problems. These include established in the first half of the last century, the Academy of Arabic Language in Cairo, main objective of which is to ensure that the Arabic language meets needs of a modern life as well as controls and approves the terms in various branches of science. In other words, the modern Arab linguistics has all the tools to solve the problems of variability of the terms raised in this article.

The very existence of lexicography terms, according to V. D. Tabanakova's opinion is already a bright confirmation of lexicography being a science (Tabanakova, 2001). Yet the formation process of theoretical lexicography as an independent field of knowledge is uneven and incomplete. Therefore, one should have effective proposals, which we believe will help in addressing difficulties of usage and lexicographical description of terms:

1) Publication of specialized journals on lexicography containing the articles devoted to problems of harmonization, standardization, and descriptions of the Arab lexicographical terminology.

2) Compilation of handbooks, glossaries and dictionaries of Arab lexicographical terms, taking into account the results of published studies and of proposed solutions in this field.

3) Creation of an online community of lexicographical terminology.

This problem is a long ago registered agenda issue. During the past thirty years, scientists from different countries were constantly addressing this issue. Krestova (2003) with a reference to Karpova (1998) notes that back in 1979, R. Kucherek raised the question of the difficulties of usage and lexicographical description of terms. A year later Dr. Gould in the professional journal of the American Lexicographic Community "Dictionaries" dwells on the topic of the need for a systematic description of lexicographical terminology. Then in 1983, R. R. K. Hartmann was one of the first who proposed a "Terminological index" which included 199 English lexicographical definitions. It is appropriate to mention here the fundamental article of W. Rigs, published in 1984 in the authoritative periodical "Lexikographica", in which the author for the first time summarizes and systematizes the problems expressed by scientists on the pages of magazines and other publications on the subject of lexicographic terminology.

Of these, Rigs highlights three major ones: "(1) problems of ambiguity; (2) problems of overabundance of terminological; (3) the problem of new concepts". Through a careful analysis of each of the above-mentioned issues, the author came to some interesting conclusions. The most recent of them reads: "to create a special language of lexicography (tehnolect) it is necessary to: (1) organize the active exchange of new publications in this field among specialists; (2) create a specific terminological column in an authoritative lexicographical magazine or newsletter; (3) to publish a dictionary of term regularly adding new units to it" (Krestova, 2003). Such efforts on the part of the scientists to give an adequate scientific description of lexicographical terminology are not rare. Based on the research by W. Rigs, B. Kipfer at the Èkseter University publishes a tutorial on lexicography with the glossary of English lexicographical terms "Workbook on Lexicography". Following him in the 1997 at the University of Oslo, the final version of the first multilingual dictionary of lexicographical 
terms "Nordisk Leksikografisk Ordbok" was published, compiled by Scandinavian scientists. A Russian lexicographer O. M. Karpova compiled a part of this dictionary in Russian, which was published in the year 2003. In 1998 at the same time. there appeared two major lexicographic works: "Dictionary of Lexicography" by R. K. K. Hartmann and G. James and "Dictionary of Lexicography Basic Terminology" by I. Burkhanov (Krestova, 2003). These works are an indispensable reference in research and analysis of theoretical and applied linguistics issues, as well as a key tool in the study of international experience in this branch of linguistics. Therefore, in the context of the growing interest in the study of the specific practice of Arabic dictionaries compilation, based today on the latest principles of world lexicography, demand the special terminological reference books, which would $100 \%$ cover all theoretical and practical apparatus of modern Arabic lexicography. Thus, according to O. M. Karpova and other scientists, the dictionary, which contains about 2000 input units, is a reputable and reliable reference covering theoretical and applied aspects of lexicography. Thus, the macrostructure of this dictionary should reflect the terms related to the typology and history, contain a description of technical characteristics and innovation in forms the vocabulary is organized in the glossary, lexicographic forms and features of the meta-language, criteria for the selection of vocabulary in dictionaries of various types, etc. A dictionary should serve as a basic reference for the researcher-lexicographer and give a full representation not only of the current status of lexicography, but also of the historical trends in the formation and development of all lexicography branches (Krestova, 2003). Basic lexicographical works in the field of Arabic lexicography can serve as the sources for the dictionary of the Arab terms. Such researchers as A. al-Qasimi, M. Hegazi, A. Omar, A. Wadghiri and their authoritative publications on lexicography like in the magazine "al-mu'jamia ak-arabia" published by the Arab lexicographical Association in Tunisia, publications on the related sciences, such as periodicals of academies of Arabic language in Cairo and elsewhere in the Arab world, the magazine "Ilm al-lugah" under the editorship of an Academician M. F. Hijazi and others can all make the base for the dictionaries.

4) The presence of professional associations, lexicographical centres where lexicographic seminars and conferences would be regularly conducted to discuss the urgent and unresolved issues, to set contacts with experts from various countries, which would collect and preserve the valuable articles, monographs, and dictionaries in several languages, which would follow the latest achievements of the modern world lexicography.

5) Development of a bilingual language Arabic Dictionaries of linguistic terms on the basis of published monolingual dictionaries, as well as specialized bilingual dictionaries of lexicographical terms taking into account the specifics of the translated language lexicography. The research in this area could serve as a basis for the creation of multilingual terminology bank in the sphere of Arabic lexicography.

\section{Conclusion}

The territorial differentiation, a well-developed diglossia, various foreign original sources, different sources within a single Arab State, polysemy, homonymy, synonymy are not only the problem of Arabic terminology, but also a difficult, although a variously solvable, problem in the process of organizing the Arab lexicographical terminology. The specific feature of Arab lexicographical terminology is that it has all the terms forming methods, including morphological, semantic, syntactic, morphological, syntactic and borrowing.

We have discussed here the meanings and terms which form part of the scientific apparatus of the Arabic lexicography quite unexplored until today by the Arabic studies. Also, an accurate analysis is required for the terms such as "al-makāniz" (Thesauruses), "al-masārid" (Glossaries,) "al-fahāris" (Concordances) as well as the metalinguistic structure of the dictionary itself, which is combined with such terms as "al-mudauuanah" (Corpus based), "al-madhnal" (Entry-dress), "al-iṇalāt" (Referential), "al-māddah" (Crude), "at-ta'sīl” (Etymological information) and others.

\section{References}

'Āyed, A. (1987). Modern Arabic lexicography. Beirut: Daral-garib al-islamy.

The Academy of the Arabic Language in Cairo. (1962). A set of scientific and technical terminology. Journal of the Arabic Language Academy, IV.

Al-Mas'udi, L. (1998). Notes on the lexicon of diplomacy and international affairs. Journal of the Arab language (in Arabic).

Al-Qasimi, A. (2003). Theoretical and practical lexicography (in Arabic). Makhtabah Lubnan nashirun.

Al-Qasimi, A. (2004). Linguistics and lexicography (in Arabic). Makhtabah Lubnan nashirun.

Al-Wadghiri, A. (1989a). Problems of Arabic dictionary in the writing of Ibn at-Tayib ash-Sharki, Riyadh (in 
Arabic).

Al-Wadghiri, A. (1989b). The issue of a "correct lexis" in Arabic historical dictionary. Journal of the Arab language (in Arabic).

Asher, R. E. (1994). The encyclopedia of language and linguistics (Vol. 10). Oxford: Pergamon Press.

Baranov, H. K. (2002). Big Arabic_-Russian dictionary. M. Russian language.

Glossary of modern linguistics. (1983). Arabic_English and English-Arabic. Beirut: Lebanon Library.

Gvishiani, N. B. (1983). To the question on meta-language of lexis. Questions on lexis, N2 (in Russian).

Hamazawi, M. R. (1984). Arab dictionary in the 20th century: Scientific apparatus, methods of collecting lexis and making a dictionary. Journal of the Arabic Language Academy (in Arabic).

Hartmann, R. R. K. (Ed.). (1983). Lexicography: Principles and Practice (Applied Language studies). London: Academic Press.

Hegazi, M. F. (1994). Linguistic research. Maktabah Garib (in Arabic).

Ibn Djinni. (1993). Mystery of grammatical analysis. In Researched and prepared for the edition: Hasan Hadawi (in Arabic). Damask: Dar al-qalam.

Intermediate dictionary of Arabic language in Cairo (5th ed.). (2011). al-shuruq al-dauliah (in Arabic).

Krestova, S. A. (2003). Dissertation written to obtain a doctoral degree in Philology on Lexicographic description of terminological system "lexicography" (in Russian).

Linguistic Encyclopedic Dictionary. (1990). Soviet Encyclopedia (in Russian).

Linguistic Encyclopedic Dictionary. (1990). Soviet Encyclopedia (in Russian). Moscow. Retrieved from http://tapemark.narod.ru/les/index.html

Malbakov, M. (2003). Dissertation written to obtain a doctoral degree in Philology on Structural basis of a dictionary of the Kazakh language (in Kazakh).

Nassar, H. (1988). Lexicon Arab origins and evolution (in Arabic). Dar Misr li at-tiba'a.

Omar, A. M. (1988). Arabic Linguistic tradition (6th ed.) (in Arabic). Cairo: Alam al-kutub.

Omar, A. M. (2009). Modern lexicography (2nd ed.) (in Arabic). Cairo: Alam al-kutub.

Svenson, B. (1993). Practical Lexicography. In Principles and Methods of Dictionary Making (Translated from Swedish by John Sykes and Kerstin Scofield). Oxford: Oxford University.

Tabanakova, V. D. (2001). Dissertation written to obtain a doctoral degree in Philology on Ideographic description of scientific terminology in special dictionaries (in Russian).

Unified terminology of linguistics. (1989). Library coordinate localization. Tunisia: ALECSO.

\section{Copyrights}

Copyright for this article is retained by the author(s), with first publication rights granted to the journal.

This is an open-access article distributed under the terms and conditions of the Creative Commons Attribution license (http://creativecommons.org/licenses/by/3.0/). 